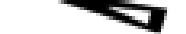

Australian Journal of
Educational Technology

\title{
Designing accessible learning materials for learners with disabilities and learning difficulties
}

\author{
Ann MacCann \\ Open Training and Education Network
}

\begin{abstract}
What do designers of learning materials need to consider in designing learning materials which may be used by learners who have physical, intellectual, vision, hearing, psychological or neurological disabilities, such as low literacy and numeracy levels? How can these materials be made more accessible for such learners? This article explains how the Open Training and Education Network has addressed this issue.
\end{abstract}

The Open Training and Education Network (OTEN) in New South Wales currently has a student population of around 27,000, enrolled in various courses in both vocational and pre-vocational areas. Because many of these courses do not require attendance at formal classes, there is a strong tendency for learners with disabilities and learning difficulties to enrol in OTEN. Instructional Designers work on developing course materials for these learners, together with teachers who are responsible for the delivery of these courses. Staff from Student Support in OTEN assist students with disabilities and/or learning difficulties (including aboriginal students and those with non-English speaking backgrounds, or NESB). These OTEN staff members recently met at a forum to discuss issues in developing courses to assist these students. The outcome of this forum is the list of recommendations, summarised in the Appendix.

\section{The students}

The number of students in OTEN who have identified themselves as having a disability or impairment is 1,279 , of whom approximately two thirds are being serviced by staff from Student Support. The disability / learning difficulty breakdown follows. 


\section{Disability}

Physical

Intellectual

Learning

Vision

Hearing

Psychiatric

Neurological and other

Totals

\section{Enrolments}

730

66

49

90

150

88

106

1279

\section{Receiving support}

420

66

49

90

120

38

80

863

The largest number of these students tend to be concentrated in:

\section{Pre-vocational courses:}

- CAFE (Certificate of Adult Foundation Education - the next step after literacy)

- CGE (Certificate of General Education - Year 8 to 10 secondary school equivalent)

- Matriculation (TAFE HSC)

\section{Vocational courses:}

- Environmental courses: mainly Aboriginal learners, who may have learning difficulties

- Child Studies: mainly Aboriginal learners

- Business courses: mainly learners with hearing disabilities.

\section{The recommendations}

These are based on the experience of teacher/consultants who deal on a daily basis with OTEN learners who have these disabilities and learning difficulties. Metacognitive strategies for learners with disabilities are dealt with in MacMillan(1986), particularly in the section entitled, Research on learning and cognition (page 696 and following). Many of the recommendations in the literature for learners with various disabilities apply to classroom learning, and integration into classes (see, for example, Sterling, 1994, Baine, 1982). However, this article discusses recommendations which apply to the development of learning materials since OTEN delivers most courses using a print component. 
1. Disk

Ensuring that learning materials are available on disk is essential for visually impaired learners. Most blind students now use computer based synthetic speech output as their primary means of accessing print. Students who are severely dyslexic and who therefore cannot access print may also manage well with a synthetic speech output program. Students with learning difficulties find that reading materials on screen seems to help them focus on what they are reading. Additionally, learners who require large print are able to work from a computer screen after changing the font style and size to one that is most appropriate to their individual needs.

Students who have a physical disability that limits fine motor control find that accessing learning materials via a computer is essential for their independence as learners. Several occasional papers on adaptive technologies for learners with disabilities are available from OTEN (Downie, 1993a, 1993b, 1995, and in press).

\section{Language use}

It seems rather obvious that all text should be written in plain English, but some vocational areas tend to bog down in difficult language. Students do need to learn the technical vocabulary appropriate to their chosen field, but this can be defined in plain English. For some learners, it is difficult to pick up technical language after one read, so designers should consider giving a variety of vocabulary building activities and practice in the use of technical language in self assessment activities throughout the text, preferably relating to the job the students are working in, or seeking. In some courses, language appropriate to the purpose may be different to what one might consider formal, written language. Some course writers have great difficulty writing in informal, conversational style: they see the print component as a textbook, rather than conducting a 'learning conversation' (see Baath, 1982). The challenge is to write in different registers for different purposes. Of course, for NESB learners, conversational English can also present a problem, so this must be carefully considered.

Learners with reading difficulties will profit from use of diagrams and clear layout with a reduced amount of text to highlight important concepts and navigate through materials.

\section{Assessment}

With the increasing implementation of competency based courses in vocational areas, course development teams need to carefully consider how outcomes should be measured. In many curricula, assessment events and criteria have already been specified, but in others they need to be 
specified by the course team in the planning phase. The following questions need to be considered: how is the learner going to use these skills on the job, and therefore how should they be measured? Can the broadest range of learners achieve them, or does the assessment criterion need to be changed? Consider oral work as well as written. Also acknowledge collaborative learning, as well as competitive (See Bryant et al, 1995 for using assistive technology to accomplish this; Goor et al, 1993 on how to do it). Many writers feel that group assessment is cheating, but on the job, many tasks are accomplished by groups.

If possible, provide alternative options to cater for different learning styles and consider the geographic restrictions of learners, such as prisoners and those with physical disabilities. In one course, learners are required to walk around a block and draw a map of a block in their local area. Prisoners were having difficulties with this! A well-constructed learner profile which includes possible minorities before the course is developed could alleviate these problems, leading to greater creativity in the planning and design of the course. There is sometimes difficulty in determining the difference between assessment for diagnostic purposes, and summative assessment. This should be clearly specified at the planning stage, so that course writers are clear about the purpose of each of the assessment items. In many of the pre-vocational courses, learners have not studied for a long time, and may not have been successful in their previous attempts at learning. Thus it is essential not to make the first assessment task too difficult, or too time consuming so learners can build up their confidence as they progress. Many mature-age NESB students aren't familiar with the system and current teaching methods, as well as lacking study skills. People involved in the delivery should also consider their role in building the confidence of students: delivery staff should be included in the design of the course. Disabilities Services (1994) has written a report for the Department of Employment, Education and Training on reasonable adjustment to competency assessment mechanisms for people with disabilities, giving examples of how this might be done (see p.47, section 4.3). One of the most important points the report makes is that (p.32) there are very different disabilities and different degrees of disability. Their summary states, (p.34) the differences within the group classified as 'people with disabilities' are actually more extreme than any differences between the group and other members of the population.

Quirk (1994) discusses issues in language and literacy affecting competency based assessment (see p.36 for a summary). He also mentions a number of projects which are related to this issue, and are ongoing at the moment (pages 33-35). 


\section{Print materials}

Designers should consider the consistency of font style and size. Use broad fonts (eg Arial, Helvetica or Universal) rather than narrower ones, which are more difficult to read. Consider how headings and text fonts interact: some designers prefer sans serif for headings, serif for text (Times is a serif font, Helvetica is a sans serif). Avoid the temptation of using too many fonts, as this can become very confusing!

Always give an overview of the learning, either in decision trees, concept or mental maps, or flow charts. This allows learners to build a mental map of what is coming, and fit it into a structure. The words mind map ${ }^{\circledR}$ have been registered as a trademark by Tony Buzan, and ideas about how to use mental maps may be gained from his book (Buzan, 1993) Ensure the structure of the materials is clear: some readers may have had the experience of checking back through a long discursive text to work out where it has come from, and where it is going as it meanders through byways. Remember that learners with physical difficulties have trouble with the physical task of frequent page turning. Some learners with neurological impairment have difficulty with diagrams, as do others with visual and intellectual disabilities, so alternate formats are helpful.

Consider how learners are going to navigate through the materials. Flag learning outcomes or objectives so learners can easily find them; cut down on referring backwards and forwards through the materials where possible. Some learners with physical disabilities have trouble with large volumes of print materials requiring them to frequently find different pages.

Use practical and concrete examples of why things are done: why these things are taught, and how they will help the learner on the job. Such explanations also assist the learner's motivation: if you know why you are learning it can be easier to learn. Use graphics and diagrams plentifully to explain concepts. However, text should be able to stand alone: learners with vision impairment need a verbal explanation as well. If the diagram is essential, simplify it so it can be generated as a raised line drawing.

Where activities or assignments require learners to walk around a block of houses, or to have a look at a library, a ground plan should be provided (for example, a typical library ground plan) for learners who have difficulty with walking or are geographically restricted. If the ground plan is what the learners need to generate, and therefore you can't provide them with it, then give a picture of a typical block with shops or houses on for them to use.

Learners with hearing impairment miss information from radio and TV programs which don't have subtitles. Learners with literacy gaps miss written information. So when you need to refer to current affairs, or 
background information from newspapers, magazines or TV programs, give this information where it is referred to (or ask the students to refer to it, giving references).

Make sure that you check the learner's understanding of the print explanation: learners with hearing impairment and literacy gaps tend to assume they have understood, but may not learn in sufficient depth to be able to use the information later. This can also apply to all other learners. It may seem obvious, but it is very important. Simplify content, and repeat in different ways, but make sure the repetition does not become boring for those who understand it the first time. State the concept, give information on how to learn it, then give the conclusion, stating the concept again. Consider emphasising the structure graphically within the text, using different fonts and / or sizes for section headings to those used in the text. For instance, OTEN uses Helvetica 18 pitch for A (or main) headings, Helvetica 14 pitch for B (or secondary) headings, with appropriate spacing, and Palatino for text. As already mentioned, use cues to assist the learner in recognising and using the structure. Use summaries at regular points throughout a topic, preferably in different ways to the text: diagram, flow chart, table. Better still, ask the learner to summarise, giving a structure, then ask them to check against the answer (on the next page only if it's not already visible while they are doing the exercise). Give positive and negative examples, to illustrate what does and does not belong to a concept, for instance, democracy: this is a very abstract and elusive concept for some learners who don't have the wealth of background information that the teacher has. Often writers overestimate the knowledge and experience of the learner.

\section{Video}

Use videos as supplements, rather than to replace parts of the course. Remember that videos are linear, and it's more difficult to revisit sections than it is to turn back the pages of a print resource (for most learners). Students need to ask themselves questions beforehand, and revise key concepts after viewing. Try asking learners to formulate their own questions beforehand. Learners can rewind the video, particularly if they are experienced in this area. However, many learners with disabilities tend to be more frightened about using technology than learners without disabilities. Subtitles are better than signing, as more people with hearing disabilities can understand them: ensure all essential videos are subtitled. Hofmeister (1992) gives guidelines on developing instructional video for a diverse group of learners.

\section{Audiotapes and video voice overs}

Make sure the voice is deep and slow, but don't use male voices only, as female learners will feel left out. Learners with neurological disabilities often have difficulty with visual presentation because their visual memory 
may be 'scrambled': they may have trouble extracting meaning from text and graphics. However they have less difficulty with aural comprehension. So an audiotape is easier for them to understand.

\section{Computers}

Many learners learn better with computers, particularly those with intellectual disabilities. Computer programs which provide multi-sensory information are extremely motivating (see EJ497680, author not stated, for a literature review and Okolo, 1993 for a retrospective view of CBI). They also provide a means of teaching learners who have limited or no reading skills. However, the information is limited by what's on the screen. Learners may feel safer because they can go back and retrieve information. Multimedia on computer taps several modalities at once, but navigation through the material needs to be carefully considered. Also ensure that the learner has access to the required computer: it is very frustrating finding out after you start that you don't have access to essential equipment. Remember that some epileptics have difficulty with the flickering screen on the computer. For a significant number of individuals with acquired brain injury (for example, through car accidents), a computer can provide practice in interaction with less boredom than, for instance, repeated practice in mathematical examples from a textbook.

\section{Learning to learn and bridging}

Learning skills should be taught as part of the content in the course. Also consider whether some learners need basic bridging skills to acquire content in particular areas: in electrical courses, there may be a need to revise algebraic concepts for the mathematics content in the course, for instance.

\section{Conclusion}

The purpose of OTEN flexible learning materials is to develop independent, autonomous learners, so there is some concern that spoon feeding learners might lead to them relying on the materials, rather than becoming independent. However materials at the start of a course, and in pre-vocational courses, need to support learners to a greater degree. This support could be gradually withdrawn as the course proceeds. In OTEN, learners may enter some courses at any point, having started with a faceto-face course, so a basic minimum of good instructional design should always be present. This will assist all learners in the course, not only those with disabilities and learning difficulties.

Remember too that not all learners with disabilities will necessarily identify themselves: learners with partial hearing impairment and reading difficulties in particular tend to shy away from defining themselves as possessing a disability. Some learners have experienced patronising treatment in previous contexts, and may wish to try independence. It's 
difficult to give blanket recommendations for all learners, as you will notice from the recommendations. Strategies which assist some learners will need to be carefully considered for others, for instance, diagrams and learners with vision impairment. However, careful consideration of the needs of all learners will result in more accessible, quality resources which meet the needs of all learners.

\section{References}

Baath, J. (1982). A list of ideas for the construction of distance education courses. In Holmberg, B. (Ed), Distance education: A short handbook. Liber Hermods, Malmo.

Baine, David (1982). Instructional design for special education. Educational Technology Publications, Inc, Englewood Cliffs, New Jersey.

Bryant, Brian R., Rivera, Diane Pedrotty (1995). Using assistive technology to facilitate cooperative learning. Paper presented at the Conference of the Florida Assistive Technology Impact and the Technology and Media Division of the Council for Exceptional Children (4th, Orlando, Florida, March 2-4, 1995).

Buzan, Tony and Buzan, Barry (1993). The Mind Map Book. BBC Books, London.

Disabilities Services (1994). Competency Assessment Mechanisms and Reasonable Adjustment. A report to the Department of Employment, Education and Training. NSW TAFE Commission, October.

Downie, Andrew (1993a). Adaptive technology survey: Equipment for people who are deaf or hearing impaired. Occasional Papers 7, OTEN, Redfern.

Downie, Andrew (1993b). Adaptive technology survey: Equipment for people who are blind or vision impaired. Occasional Papers 8, OTEN, Redfern.

Downie, Andrew (1995). Adaptive technology survey: Equipment for people who have a physical disability. Occasional Papers 9, OTEN, Redfern.

Downie, Andrew (in press). Equipment for people who have intellectual, neurological or learning disabilities. Occasional Papers, OTEN, Redfern.

EJ497680 (1995). Instructional design of computer assisted instruction for use with students who have mild disabilities. Teaching Exceptional Children, 27(3, Spring), 77-79 (this reference has no author, either in the journal or in the ERIC listing).

Goor, Mark B. and Schwenn, John O. (1993). Accommodating diversity and disability with cooperative learning. Intervention in School and Clinic, 29(1, September), 6-16.

Hofmeister, (1992). Learner diversity and instructional video: implications for developers. Educational Technology, 32(7, July), 13-16.

MacMillan, Donald L., Keogh, Barbara K. and Jones, Reginald L. (1996). Special educational research on mildly handicapped learners. In Merlin C. Wittrock (ed), Handbook of Research on Teaching, third edition. Macmillan Publishing Company, New York.

Okolo, Cynthia M., Bahr, C. and Reith, H. (1993). A retrospective view of computer based instruction. Journal of Special Education Technology, 12(1, Spring), 1-27.

Quirk, Robert (1994). Language and Literacy issues in competency based assessment. Prepared for the Assessment Centre for Vocational Education; the project was commissioned by the Foundation Studies Training Division (TAFE NSW) utilising funding supplied by the Education and Training Foundation, October.

Sterling, Leith (1994). Students with Acquired Brain Injuries in Primary and Secondary Schools. Draft report of the project by the Head Injury Council of Australia, funded by the Commonwealth Department of Employment, Education and Training (details of printing location not available in document). 
Appendix: Recommendations for designing accessible learning materials

\begin{tabular}{|c|c|c|}
\hline & Recommendation & Student group \\
\hline 1. Disk & $\begin{array}{l}\text { All material should be available on } \\
\text { disk. }\end{array}$ & $\begin{array}{l}\text { All learners, particularly } \\
\text { with vision impairment or } \\
\text { physical disabilities and } \\
\text { specific learning } \\
\text { disabilities. }\end{array}$ \\
\hline $\begin{array}{l}\text { 2. Language } \\
\text { use }\end{array}$ & $\begin{array}{l}\text { All text should be written in plain } \\
\text { English. Consider giving practice in } \\
\text { the use of technical language in the } \\
\text { self assessment activities. Also, } \\
\text { consider language appropriate to the } \\
\text { purpose: different registers are } \\
\text { acceptable for different purposes. Use } \\
\text { key and go words to highlight } \\
\text { important concepts and navigate } \\
\text { through materials. }\end{array}$ & $\begin{array}{l}\text { All learners, particularly } \\
\text { learners with reading } \\
\text { difficulties, such as NESB } \\
\text { (English as a second } \\
\text { language), specific reading } \\
\text { disability. Aboriginal } \\
\text { learners or those with } \\
\text { intellectual disabilities and } \\
\text { hearing impairment. }\end{array}$ \\
\hline \multirow[t]{2}{*}{ 3. Assessment } & $\begin{array}{l}\text { Consider how outcomes are } \\
\text { measured: can the broadest range of } \\
\text { students achieve them or does the } \\
\text { assessment criterion need to be } \\
\text { changed? Consider oral work as well } \\
\text { as written. Also acknowledge } \\
\text { collaborative learning as well as } \\
\text { competitive: it's not cheating. Provide } \\
\text { alternative options, to cater for } \\
\text { different learning styles and } \\
\text { restrictions (prisoners physical } \\
\text { disabilities). }\end{array}$ & $\begin{array}{l}\text { All learners, particularly } \\
\text { learners with reading } \\
\text { difficulties, such as NESB, } \\
\text { specific reading disability, } \\
\text { Aboriginal, prisoners, or } \\
\text { learners with physical } \\
\text { disabilities or vision } \\
\text { impairment. } \\
\text { This may help the isolating } \\
\text { effects of any disability. }\end{array}$ \\
\hline & $\begin{array}{l}\text { The first assignment should not be too } \\
\text { difficult, and preferably not receive a } \\
\text { mark or be part of the final mark for } \\
\text { the subject/module. }\end{array}$ & $\begin{array}{l}\text { All learners, particularly } \\
\text { learners with reading } \\
\text { difficulties, Aboriginal, } \\
\text { prisoners, NESB, or } \\
\text { learners with intellectual } \\
\text { disabilities. }\end{array}$ \\
\hline \multirow[t]{2}{*}{$\begin{array}{l}\text { 4. Print } \\
\text { material } \\
\text { design }\end{array}$} & $\begin{array}{l}\text { Text font, style and size } \\
\text { Font size should be 12, including } \\
\text { tables, and font style and size should } \\
\text { be consistent. Use broad fonts (eg } \\
\text { Ariel, Helvetica or Universal) rather } \\
\text { than narrower ones. }\end{array}$ & $\begin{array}{l}\text { All learners, particularly } \\
\text { learners with vision } \\
\text { impairment. }\end{array}$ \\
\hline & $\begin{array}{l}\text { An overview of the learning should } \\
\text { be given either in decision trees, } \\
\text { concept or mental maps, flow charts } \\
\text { (but remember some learners have } \\
\text { difficulty with graphics, so these }\end{array}$ & $\begin{array}{l}\text { All learners, particularly } \\
\text { learners with learning } \\
\text { difficulties, physical or } \\
\text { neurological disabilities } \\
\text { and NESB learners. }\end{array}$ \\
\hline
\end{tabular}




\begin{tabular}{|c|c|}
\hline $\begin{array}{l}\text { should not be stand alone). Make sure } \\
\text { the content is in small chunks. Ensure } \\
\text { the structure of the materials is clear. }\end{array}$ & \\
\hline $\begin{array}{l}\text { Use lots of graphics and diagrams, } \\
\text { however text should be able to stand } \\
\text { alone (don't use only a diagram to } \\
\text { explain a concept: use text and the } \\
\text { diagram). If the diagram is essential, } \\
\text { simplify so it can be generated as a } \\
\text { raised line drawing. }\end{array}$ & $\begin{array}{l}\text { Aboriginal, NESB and } \\
\text { learners with reading } \\
\text { difficulties, those with } \\
\text { neurological disabilities or } \\
\text { vision impairment. }\end{array}$ \\
\hline $\begin{array}{l}\text { Where activities or assignments } \\
\text { require students to (for instance) walk } \\
\text { around a block of houses, or to have a } \\
\text { look at a library, a ground plan } \\
\text { should be provided (for example, a } \\
\text { typical library ground plan) for } \\
\text { students who have difficulty. }\end{array}$ & $\begin{array}{l}\text { Geographically isolated, } \\
\text { prisoners, learners with } \\
\text { physical or vision } \\
\text { impairment. }\end{array}$ \\
\hline $\begin{array}{l}\text { Navigation through the materials } \\
\text { should be considered: flag learning } \\
\text { objectives / outcomes so learners can } \\
\text { easily find them; cut down on } \\
\text { referring backwards and forwards } \\
\text { through the materials where possible. }\end{array}$ & $\begin{array}{l}\text { All learners, particularly } \\
\text { NESB, those with } \\
\text { neurological disabilities or } \\
\text { vision impairment. }\end{array}$ \\
\hline $\begin{array}{l}\text { Background information given, where } \\
\text { referred to, as learners with hearing } \\
\text { impairment miss information from } \\
\text { radio and TV which doesn't have } \\
\text { subtitles, and literacy learners miss } \\
\text { written information. }\end{array}$ & $\begin{array}{l}\text { All learners, particularly } \\
\text { literacy, hearing and } \\
\text { neurological disabilities. } \\
\text { This can help develop a } \\
\text { contextual 'map'. }\end{array}$ \\
\hline $\begin{array}{l}\text { Reading for understanding: make } \\
\text { sure that understanding of the print } \\
\text { explanation is checked. Learners with } \\
\text { literacy gaps or hearing impairment } \\
\text { tend to assume they have understood, } \\
\text { but may not learn in sufficient depth. } \\
\text { Learners may also be unwilling to } \\
\text { admit they have not understood. }\end{array}$ & $\begin{array}{l}\text { All learners, particularly } \\
\text { with reading difficulties, } \\
\text { hearing and neurological } \\
\text { disabilities. }\end{array}$ \\
\hline $\begin{array}{l}\text { Simplify content and repeat in } \\
\text { different ways, but make sure the } \\
\text { repetition does not become boring for } \\
\text { those who understand it the first time. } \\
\text { State the concept, give information on } \\
\text { how to learn it, then give the } \\
\text { conclusion, stating the concept again. } \\
\text { Consider emphasising the structure } \\
\text { graphically, using different section } \\
\text { headings to text. }\end{array}$ & $\begin{array}{l}\text { Learners with learning or } \\
\text { neurological disabilities or } \\
\text { those with hearing } \\
\text { impairment. }\end{array}$ \\
\hline
\end{tabular}




\begin{tabular}{|c|c|c|}
\hline & $\begin{array}{l}\text { Use cues to assist the student in } \\
\text { recognising and using the structure. } \\
\text { Use summaries at regular points } \\
\text { throughout a topic, preferably in } \\
\text { different ways to the text: diagram, } \\
\text { flow chart, table. Give positive and } \\
\text { negative examples to illustrate what } \\
\text { does and does not belong to a } \\
\text { concept, for instance democracy. }\end{array}$ & $\begin{array}{l}\text { All learners, particularly } \\
\text { those with learning and } \\
\text { neurological disabilities. }\end{array}$ \\
\hline \multirow[t]{2}{*}{ 5. Video } & $\begin{array}{l}\text { Use videos as supplements rather } \\
\text { than to replace parts of the course. } \\
\text { Remember that videos are linear and } \\
\text { it's difficult to revisit sections, so } \\
\text { prepare questions beforehand and } \\
\text { revise key concepts after viewing. }\end{array}$ & $\begin{array}{l}\text { All learners, particularly } \\
\text { those with vision } \\
\text { impairment. }\end{array}$ \\
\hline & $\begin{array}{l}\text { Subtitles are better than signing, as } \\
\text { more people with hearing impairment } \\
\text { can understand them: ensure all } \\
\text { essential videos are subtitled. }\end{array}$ & $\begin{array}{l}\text { Learners with hearing } \\
\text { impairment. }\end{array}$ \\
\hline 6. Audiotapes & $\begin{array}{l}\text { Make sure the voice is deep and slow, } \\
\text { but don't use male voices only. Use as } \\
\text { alternate presentation of content to } \\
\text { print. }\end{array}$ & $\begin{array}{l}\text { Learners with hearing } \\
\text { impairment, or vision } \\
\text { impairment learners with } \\
\text { neurological disability. }\end{array}$ \\
\hline 7. Computers & $\begin{array}{l}\text { Learners with intellectual disabilities } \\
\text { learn better with computers. They } \\
\text { find them motivating. The } \\
\text { information is limited by what's on } \\
\text { the screen. They may feel safer } \\
\text { because they can go back and retrieve } \\
\text { information. Multimedia on computer } \\
\text { also taps several modalities at once. }\end{array}$ & $\begin{array}{l}\text { Learners with learning or } \\
\text { neurological disabilities }\end{array}$ \\
\hline $\begin{array}{l}\text { 8. Learning to } \\
\text { learn }\end{array}$ & $\begin{array}{l}\text { Learning skills should be taught as } \\
\text { part of the content in the subject. } \\
\text { Some students need basic bridging } \\
\text { skills to acquire content in particular } \\
\text { subject areas. }\end{array}$ & $\begin{array}{l}\text { All learners, particularly } \\
\text { NESB, Aboriginals, those } \\
\text { with reading disabilities, } \\
\text { neurological, or learning } \\
\text { disabilities or hearing } \\
\text { impairment. }\end{array}$ \\
\hline
\end{tabular}




\section{Acknowledgments}

I would like to acknowledge the assistance of the following OTEN staff:

Sue Clilverd, Educational Operations Manager

Merren Dargan, Teacher/Consultant, vision impairments

Pam Jackson. Aboriginal Development Manager

Marea Jordan Watt, Teacher/Consultant, physical disabilities

David King, Teacher/Consultant, physical disabilities

Wendy McLachlan, Teacher/Consultant, neurological disabilities

Aida Tabet, Multicultural Education Coordinator

Debbie Trevan, Teacher/Consultant, intellectual and learning disabilities

Andrew Young, Teacher/Consultant, hearing impairment

Andrew Downie, Teacher/Consultant, Adaptive Technology

Daphne Gonzalvez, Instructional Designer

Gail Sawle, Teacher, ESOL

Ann MacCann is an Instructional Designer in ETRC, Open Training and Education Network, Sydney, NSW.

Please cite as: MacCann, A. (1996). Designing accessible learning materials for learners with disabilities and learning difficulties. Australian Journal of Educational Technology, 12(2), 109-120.

http: / / www.ascilite.org.au/ajet/ajet12 / maccann.html 